\title{
The Corneal Endothelium in Children after Congenital Cataract Surgery-A Comparison of Pre- and Post-0perative Results
}

\author{
Ewa Porwik, Erita Filipek, Maria Formińska-Kapuścik \\ Ophthalmology Clinic and Department of Ophthalmology, School of Medicine in Katowice, Medical University \\ of Silesia in Katowice, Katowice, Poland \\ Email: porwikewa@gmail.com
}

Received 26 February 2015; accepted 8 May 2015; published 11 May 2015

Copyright $(2015$ by authors and Scientific Research Publishing Inc.

This work is licensed under the Creative Commons Attribution International License (CC BY). http://creativecommons.org/licenses/by/4.0/

(c) (7) Open Access

\begin{abstract}
Three months after surgery, the research group showed significantly statistical improvement in visual acuity, a statistically significant decrease in corneal endothelial cell density, a statistically significant increase in the percentage of 5 and 8 sided cells and a statistically significant decrease in the percentage of six sided cells. Central corneal thickness and the percentage of 4 and 7 and more than 8 sided did not change in a statistically significant way. Comparing the test group and control group, no statistically significant differences were detected in the examined parameters. The present study also shows that the cornea in the eyes with congenital cataract does not show statistically significant changes in the density and the morphology of the corneal endothelial cells and the thickness of the cornea and in terms of corneal thickness in comparison to the corneas of healthy eyes. Although in corneas undergoing cataract occurs statistically significant changes, the influence of the cornea does not affect the improvement in visual acuity which was also demonstrated in this study.
\end{abstract}

Keywords

Congenital Cataract Surgery, Corneal Endothelial Cells, Pleomorphism, Polimegatism

\section{Introduction}

The main function of the corneal endothelium is to maintain proper corneal hydration, thus ensuring transparency of the cornea through the activity of an ion pump which, in turn, is controlled by the endothelial cells' $\mathrm{Na}^{+} / \mathrm{K}^{+}$ATP-asa. If there is a $500 / \mathrm{mm}^{2}$ loss in corneal endothelial density, the pump's endothelial cells are im- 
paired, leading to corneal decompensation, haziness, and a resulting deterioration of the subject's vision. The cornea's endothelium has two primary functions: a barrier that permits a flow of dissolved nutrients and metabolites between the aqueous humor and the corneal stroma, and as a pump to maintain the correct tension of the cornea. The proper functioning of this pump ensures a translucent cornea. Changes in the quantitative and qualitative composition of the cornea's endothelium provide information about its operation. Many factors influence the corneal endothelium. These include systemic diseases such as diabetes, trauma, and the aging process. The corneal endothelium's fundamental characteristic is its endothelial cell density. This measurement can be supplemented by two additional evaluations: the endothelium's pleomorphism and its polimegatysm. Pleomorphism is an indicator of endothelial cell shape; polimegatysm is an indicator of the size of the endothelial cells. Using a microscope, endothelial abnormalities can be identified in a corneal endothelium's morphology. The corneal endothelium, consisting of hexagonal or hexagonal-like cells, is the cornea's single innermost mosaic. Doughty [1] observed that, these cells comprised around $60 \%$ of the cornea's cells; the remainder of them were exclusively four, five, seven or eight-sided cells [1]. Upon any loss of the normal hexagonal cells, the surrounding cells must then change their hexagonal shape, extending themselves to compensate for the endothelium's deficiencies caused by this cell loss. This results in an endothelium with a reduced number of properly hexagonal cells and an increased number of pleomorphic cells.

There are many factors that affect the corneal endothelium. Nucci et al., Koraszewska-Matuszewska and Dong observed that the primary factor was the subject's age [2]-[4]. The current literature presents a fairly wide range for standard endothelial cell density, from 3000 to 7500 cells per $\mathrm{mm}^{2}$. Following the first years of life, a sharp drop in the number of endothelial cells is observed, which is explained by the intensive growth of the eyeball during this time. It has been assumed by Nucci that, during the first year of life, the number of corneal endothelial cells reduces by $45 \%$ with the endothelial cell density falling to approximately $2700 / \mathrm{mm}^{2}$ by the age of five years [2]. According to Koraszewska-Matuszewska from the age of 18 years onwards there is a corneal endothelial cell loss of $0.5 \%$ per year [3]. Bourne \& McLaren observed that cell polimegatism increased with age, with the number of normal hexagonal cells decreasing [5]. While multiple publications have assessed agerelated changes in corneal endothelial cell density, not one scientific report available has looked at changes in endothelial cell morphology such as the cells' size and their shape. It has been accepted that endothelial pump activity decreases with age, even though the process of endothelial cell loss has not yet been fully elucidated. Some authors, Cho, Rieck, and Wetson, have described the processes of induced apoptosis which could influence this aforementioned decrease [6]-[8]. The processes involved in release apoptosis in the human cornea were not fully understood, but Rieck considered that these may be a result of metabolic changes, mechanical stress, endotoxins, the loss of protective factors, or nutrient deprivations [7]. It has been described by Wetson how pro-inflammatory cytokines can cause corneal endothelial apoptosis [8]. In addition, many intracellular proteins are involved in either the induction, or the prevention, of apoptosis [8]. The corneal endothelium is affected by associated diseases such as glaucoma or inflammatory process in the anterior segment of the eye. It has been proven by Larsson that elevated intraocular pressure damages the corneal endothelium if it lasts for longer than three days [9]. The corneal endothelium is also affected by the wearing of contact lenses. Contact lenses worn for long periods of time alter the endothelium's morphology. Specular microscope studies have shown an increased polimegatism and polymorphism of endothelial cells, after the wearing of contact lenses. However, these changes were not observed by Cho to affect endothelial cell function or density [6]. Any trauma that disrupts the entire structure of the cornea is another factor that would influence the corneal endothelium. General diseases are another cause that affects the corneal endothelium, with the best-known general illness of this type being diabetes. While diabetes does not affect the density of the endothelial cells, it has been proven by Wetson and Larsson that it does cause an increase in corneal thickness and changes in endothelial cell morphologic characteristics [8] [9]. During surgery, any corneal rupture changes both the morphology and the density of endothelial cells. One example, cataract surgery, causes some endothelial cell loss, the extent of which is difficult to estimate prior to the surgery. Abnormalities in the density or morphology of endothelial cells prior to cataract surgery increase the risk of postoperative corneal decompensation. Such outcomes should be the subject of more extensive investigations.

Previous research has examined neither the distribution of corneal endothelial cells of different shapes in healthy corneas, nor if in some way this distribution differs from the endothelial cell distribution found in eyes with cataracts. The purpose of this paper is to present the distribution of different shapes of endothelial cells in the corneas of healthy eyes, in the corneas of those eyes with cataracts, and to compare the primary parameters 
of these two eye populations. In addition, this study seeks to compare preoperative with postoperative corneal parameters following surgery for congenital cataracts.

\section{Patients and Methods}

The research group consists of 31 eyes of 26 children (16 girls and 10 boys) aged 3 - 17 (mean age 8.46) with congenital cataracts. Unilateral cataract was observed in 21 children and bilateral cataract was observed in 5 children. Procedures were carried out in the years 2011-2013 in the Department of Pediatric Ophthalmology in Katowice. All children underwent cataract surgery by facoaspiration with simultaneous implanting an artificial intraocular lens foldable acrylic in the capsular bag. All patients were implanted with acrylic lens of the same model. Opacified lens was removed by irrigation and aspiration after a circular cut-out of the anterior capsule of the lens. The artificial lens was implanted into the capsular bag. In children under five years of age additional recess in the central portion of the posterior capsule of the lens was made and the cut out front of the vitreous body through this opening. Each patient enrolled in the study underwent, with their parents, a detailed interview. The following measurements were also collected: visual acuity at distance checked through the use of Snellen charts; the front section of each eye was examined using a slit lamp; and an endothelial microscope was used to collect the primary research parameters (polimegatism and pleomorphism). The studies used a microscope endothelial MOD SP-02 CSO (Costruzione Strumenti Oftalmici). These measurements were carried out one day before and three months after surgery undertaken to remove the lens and implant an artificial intraocular lens. The control group were children once tested before surgery—21 non-operated, healthy associated eyes in 21 children aged 3 to 17 years old children with unilateral cataracts (mean age 8.60).

The criteria for inclusion:

- congenital cataracts;

- aged younger than 18 years.

The criteria for exclusion:

- patients with a history of, or currently active, inflammatory process within the eyeball (with the exception of conjunctivitis);

- patients wearing contact lenses;

- patients with a history of surgery;

- patients with associated ocular diseases;

- patients with general diseases;

- patients with ocular trauma.

\section{Results}

Comparing the test group and the control group, no statistically significant differences were detected in the examined measurable properties. The pleomorphism seen in the test group and in the control group exhibited no statistically significant differences (Table 1, Table 2, Figure 1, Table 3).

Three months following the surgery, the research group showed a statistically significant improvement in visual acuity, a statistically significant increase in the percentage of five and eight-sided cells, a statistically significant decrease in the percentage of six sided cells and a statistically significant decrease in corneal endothelial

Table 1. Comparison of endothelial cells with specific number of sides in children in control group and in the analyzed group before operation.

\begin{tabular}{cccc}
\hline Cell sides & Control group & Analyzed group before operation & $p$ \\
4 & 1.428 & 1.937 & 0.340 \\
5 & 17.5 & 17.656 & 0.979 \\
6 & 61 & 59.750 & 0.685 \\
7 & 18.142 & 18.656 & 0.667 \\
8 & 1.523 & 2.000 & 0.465 \\
$8+\mathrm{n}$ & 0.095 & 0.031 & 0.333 \\
\hline
\end{tabular}




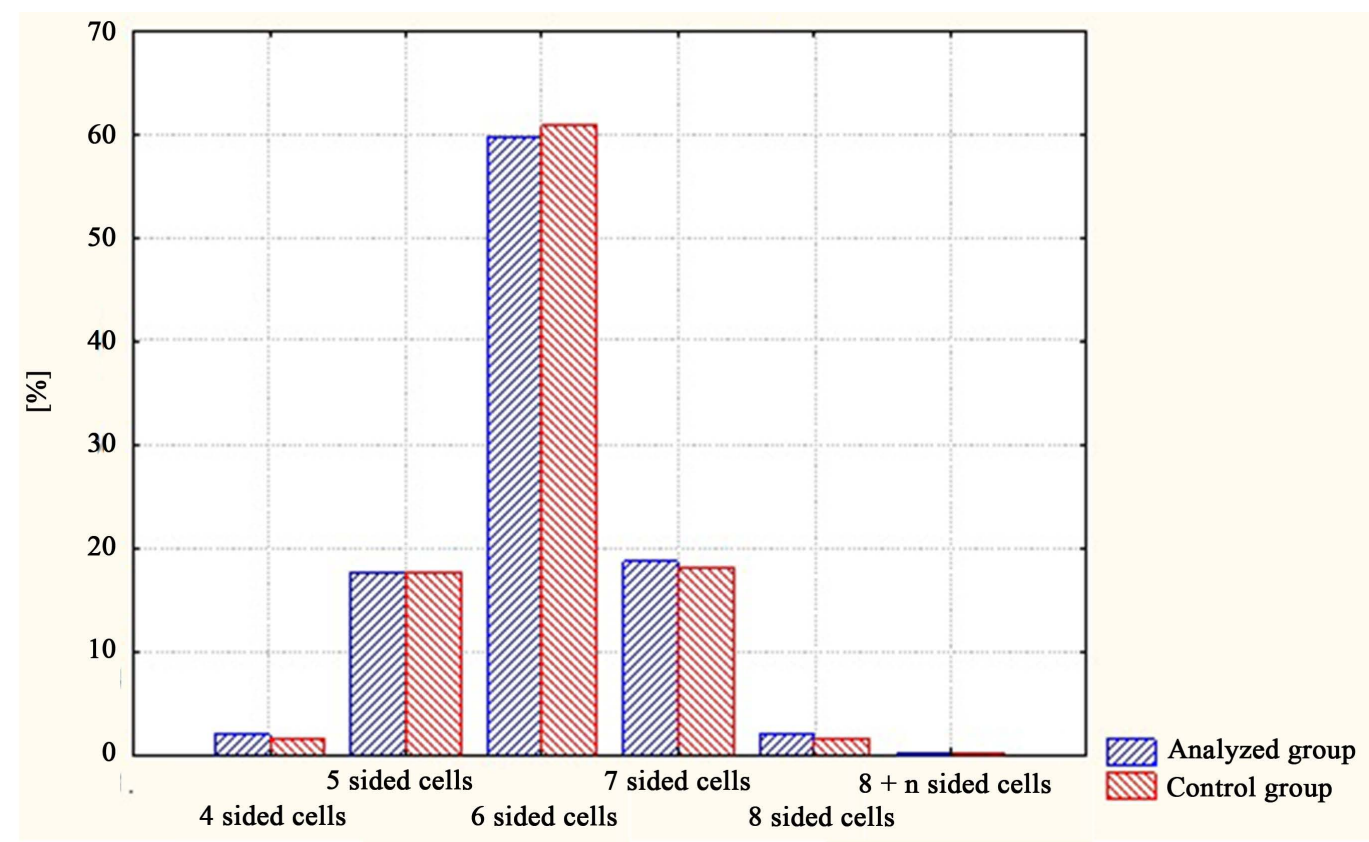

Figure 1. The proportion of endothelial cells with a specific number of sides in children in control and in the analyzed group.

Table 2. Standard deviation in evaluated parameters in control and analyzed group.

\begin{tabular}{ccc}
\hline Parameter & Standard deviation (analyzed group) & Standard deviation (control group) \\
\hline A4 & 2.16 & 1.86 \\
A5 & 4.20 & 5.48 \\
A6 & 7.43 & 11.30 \\
A7 & 4.00 & 4.24 \\
A8 & 2.80 & 2.58 \\
A8 $+\mathrm{n}$ & 0.18 & 0.18 \\
\hline
\end{tabular}

Table 3. Comparison of endothelial cell density and central corneal thickness between control and analyzed group before operation.

\begin{tabular}{ccccc}
\hline Parameter & Analyzed group before operation & Control group & p & Significance \\
\hline Endothelial cell density $\left(\mathrm{cell} / \mathrm{mm}^{2}\right)$ & $3,071,226$ & 3200.571 & 0.379 & NS \\
Central corneal thickness $\left(\mu \mathrm{m}^{2}\right)$ & 590,096 & 605.714 & 0.176 & NS \\
\hline
\end{tabular}

NS: statistically non significant, S: statistically significant.

cell density. Amongst the other measurable properties observed, the central corneal thickness and the percentage of four, seven, and more than eight-sided cells did not change in a statistically significant way (Table 4, Figure 2, Table 5, Figure 3, Table 6).

\section{Discussion}

The basic measurable property providing information about the outcome of cataract surgery is visual acuity. The results obtained from our investigation are in accordance with those found in the international literature; that is, 


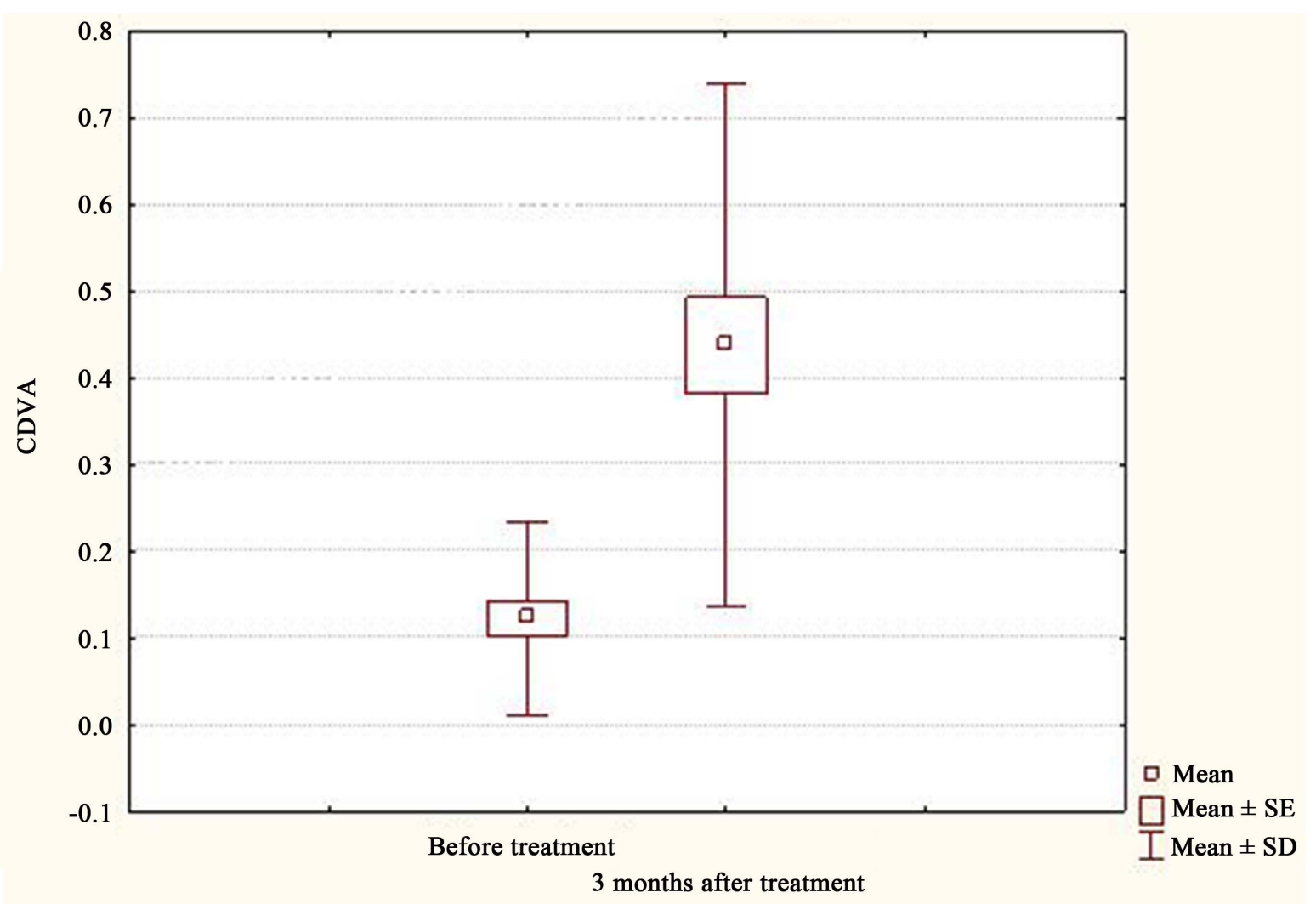

Figure 2. Comparison of corrected distance visual acuity before and 3 months after treatment in analyzed group.

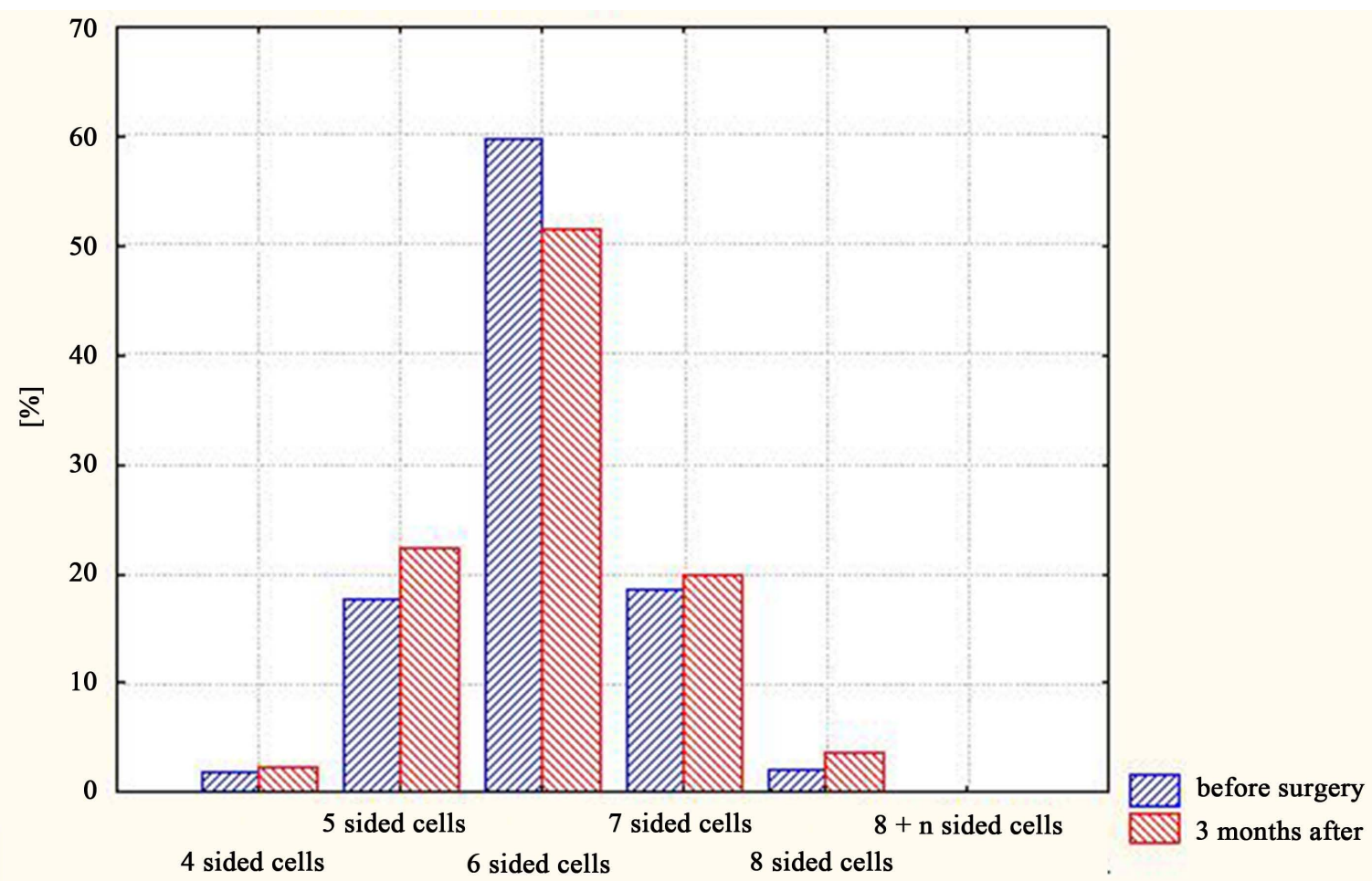

Figure 3. The proportion of endothelial cells with a specific number of sides in children before and 3 months after cataract surgery. 
Table 4. Mean value of corrected distance visual acuity before and 3 months after treatment in analyzed group.

\begin{tabular}{ccc}
\hline CDVA & Mean & $\mathrm{p}$ \\
\hline Before treatment & 0.1 & $\mathrm{p}<0.05$ \\
3 months after & 0.4 & \\
\hline
\end{tabular}

Table 5. Comparison of endothelial cells with a specific numbers of sides in children before and 3 months after treatment.

\begin{tabular}{|c|c|c|c|}
\hline Cell sides & Analyzed group before treatment & Analyzed group 3 months after treatment & $\mathrm{p}$ \\
\hline 4 & 1.937 & 2.343 & 0.49 \\
\hline 5 & 17.656 & 22.406 & $\mathrm{p}<0.05$ \\
\hline 6 & 59.750 & 51.531 & $\mathrm{p}<0.05$ \\
\hline 7 & 18.656 & 19.937 & 0.10 \\
\hline 8 & 2.000 & 3.718 & $\mathrm{p}<0.05$ \\
\hline $8+n$ & 0.031 & 0.031 & 1.00 \\
\hline
\end{tabular}

Table 6. Changes in three evaluated parameters before and 3 months after treatment in analyzed group.

\begin{tabular}{cccc}
\hline Parameter & $\begin{array}{c}\text { Analyzed group before treat- } \\
\text { ment }\end{array}$ & $\begin{array}{c}\text { Analyzed group } \\
\text { 3 months after treatment }\end{array}$ & S \\
\hline Endothelial cell density $\left(\right.$ cell $\left./ \mathrm{mm}^{2}\right)$ & 3071.226 & 2685.839 & $<0.05$ \\
Central corneal thickness $\left(\mu \mathrm{m}^{2}\right)$ & 590.096 & 592.6129 & $\mathrm{~S}$ \\
\hline
\end{tabular}

NS: statistically non significant, S: statistically significant.

in studies conducted by other researchers, the visual acuity was of a similar level as the visual acuity observed in our study. For example, for patients with traumatic and congenital cataracts, Bakunowicz-Łazarczyk gave a postoperative visual acuity in the range $0.1-0.4$ in $65 \%$ of patients [10]. Brady studied children with bilateral cataract development and those with unilateral congenital or developmental cataracts [11]. All the children with bilateral cataracts had postoperative visual acuity of 0.5 or better. In children with unilateral cataracts, visual acuity was $0.1-0.5$. Leurence reported that when examining children in whom an artificial posterior chamber lens had been implanted following a traumatic or congenital cataract, $90 \%$ of this sample achieved a visual acuity 0.3 [12]. Spierer studied 50 eyes of children with congenital cataract and found that postoperative visual acuity was 0.5 or better in one third of their patients [13]. Yao studied 27 eyes of children with congenital cataracts, finding that in all of these eyes the visual acuity after 10 months was 0.5 [14]. Filipek has noted that when 80 eyes of children were examined following developmental cataracts and the implantation of a posterior chamber foldable intraocular lens, the visual acuity achieved in all of these eyes was 0.6 [15]. Their observation period was, on average, 3.6 years. Filipek also present the results of tests on 105 eyes operated on due to developmental cataracts (the follow-up time here was 4.2 years), finding that the average visual acuity in children operated on due to unilateral cataracts was 0.3 , while in children operated on due to bilateral cataracts it was 0.6 [16]. In the subsequent publication, Filipek wrote that 33 eyes operated on due to congenital cataracts (a mean follow-up time of 36.3 months), a visual acuity of 0.1 was achieved for those previously with unilateral cataracts cases, 0.2 for those formerly with bilateral cataracts [17]. The corneal endothelium is primarily responsible for the maintenance of normal turgor and transparency in the cornea. Thus, the endothelial condition should be evaluated in vivo both before and after surgery. Cell density is a good indicator of the endothelial state. It was proven by Szalai and Bourne that conducting research using an endothelial microscope allows for the detection of clinically normal corneas, the detection of small changes and of the pathological changes also seen in clinical examinations [18] [19]. To date there has been only a very small number of reports providing information on the loss of endothelial cells in children. All authors agree that the greatest loss of endothelial cells occurs in the early postoperative period (on a timescale of weeks); the existence of a corneal endothelium stabilization period remains controversial Liesang \& Bourne and Galin \& Lin hold that it is 3 months after surgery, Olsen 6 months after 
surgery and Mrzygłód hold the view that one year [20]-[23]. A large loss of endothelial cells has been associated with the material from which the lenses have been made. As medical science has developed, the material from which lens are constructed has improved, leading to better clinical results. According to the data provided by Urban, endothelial cell loss in children following cataract surgery with facoaspiration and artificial lens implantation was $10.94 \%$ after one month and $17.85 \%$ after six months [24]. According to a recent study by Vasavada three months after cataract surgery with simultaneous implantation of a lens, the corneal endothelial cell loss was $5.1 \%$ in children [25]. Basti have indicated that endothelial cell loss following extracapsular cataract surgery in children ranged from $5.28 \%$ to $7.50 \%$ during observation periods of 24 - 36 weeks [26]. According to Koraszewska-Matuszewska the average loss of endothelial cells in children six months after extracapsular congenital cataract surgery ranged from $8 \%$ to $27.8 \%$ (the mean loss was $11.2 \%$ ) [3]. Most of the available research refers to changes in the corneal thickness seen in adults following cataract phacoemulsification surgery and intraocular lens implantation. The results obtained by this paper's authors: Hengerer and Lundberg are consistent with those observed elsewhere, in that they confirm that in the postoperative period there is an increase in the central corneal thickness (of around 6\% to 15\%) [27] [28]. There are, however, very few scientific reports that compare central corneal thickness before and after surgery for congenital cataracts accompanied by the implantation of an intraocular lens. Faramazi analyzed corneal thickness in 32 pseudophakic eyes and 15 aphakic eyes [29]. The tests were performed one month and six months after the operation. The average thickness of the cornea before surgery in the pseudophakic group of children was $540 \pm 34$; a month after surgery it was $587 \pm$ 65. Six months after the procedure there was a return to pre-surgery levels, with central corneal thickness being found to be $540 \pm 36$. These changes were not statistically significant. Vasavada studied 100 eyes of children with congenital cataracts [25]. The central corneal thickness was measured before cataract surgery, after the implantation of an artificial lens, and three months following the surgery. Before surgery, the mean central corneal thickness was $529 \pm 30$; three months after surgery it was $527 \pm 34$. These changes were also not statistically significant. Pleomorphism is an indicator of the shape of the corneal endothelial cells. Polimegatism is an indicator of the size of the corneal endothelial cells. Polimegatism and pleomorphism are both measures that can be used to assess physiological imbalance or dysfunction in a cornea's endothelium. To date, the reported research has looked at changes in the hexagonal cells that are considered to form the physiological corneal endothelium. A high percentage of hexagonal cells has been used as an indicator of a healthy corneal endothelium. Vasavada have reported that the percentage of hexagonal cells dropped from 58.1 to 48.6 three months subsequent to congenital cataract surgery while, according to Basti this decrease is from $65.13 \%$ to $57.75 \%$ [25] [26]. The results obtained from our research are very similar to those presented here. However, no prior publication has described the changes seen in the shape of all of the cells that comprise the corneal endothelium. Also, none of the publications presented here has described changes in the size of the cells that comprise the corneal endothelium.

\section{Conclusion}

The above data indicate that the most sensitive evaluative parameters that can provide information about changes in the state of the cornea are the proportion of five-sided cells, the proportion of six-sided cells and changes in endothelial cell density. Eight-sided cells also serve as a sensitive indicator of the changes undergone by a cornea that has been subjected to surgery. Here, these indicators have neither been specifically studied nor described. The present study also demonstrates that in eyes with congenital cataracts, the cornea does not show any statistically significant change in the density or morphology of its corneal endothelial cells, nor in the cornea's thickness in comparison to healthy eyes' corneas. While, in corneas undergoing cataract surgery, there are statistically significant changes, the cornea does not appear to affect the improvement that is observed in visual acuity, an improvement that is also statistically significant as demonstrated in this study. This suggests that, in children, cataract surgery utilizing irrigation and aspiration is safe.

\section{References}

[1] Douhty, M.J. (1998) Prevalence of "Non-Hexagonal” Cells in the Corneal Endothelium of Young Caucasian Adults, and Their Inter-Relationships. Ophthalmic and Physiological Optics, 18, 415-422. http://dx.doi.org/10.1046/j.1475-1313.1998.00376.x

[2] Nucci, P., Brancato, R., Mets, M.B. and Shevell, S.K. (1990) Normal Endothelial Cell Density Range in Childhood. Archives of Ophthalmology, 108, 247-248. http://dx.doi.org/10.1001/archopht.1990.01070040099039 
[3] Koraszewska-Matuszewska, B., Samochowiec-Donocik, E., Papież, M., Filipek, E. and Bolek, S. (1992) Examination of Corneal Endothelium after Cataract Extraction in Children. Klinika Oczna, 94, 338-340.

[4] Dong, X.G. (1993) An Evaluation of Corneal Endothelial Damage Following Intraocular Lens Implantation. Chinese Journal of Ophthalmology, 29, 346-348.

[5] Bourne, W. and McLaren, J.W. (2004) Clinical Responses of the Corneal Endothelium. Experimental Eye Research, 78, 561-572. http://dx.doi.org/10.1016/j.exer.2003.08.002

[6] Cho, K.S., Lee, E.H., Choi, J.S. and Joo, C.K. (1999) Reactive Oxygen Species-Induced Apoptosis and Necrosis in Bovine Corneal Endothelial Cells. Investigative Ophthalmology and Visual Science, 40, 911-919.

[7] Rieck, P.W., Gigon, M., Jaroszewski, J., Pleyer, U. and Hartmann, C. (2003) Increased Endothelial Survival of OrganCultured Corneas Stored in FGF-2-Supplemented Serum-Free Medium. Investigative Ophthalmology and Visual Science, 44, 3826-3832. http://dx.doi.org/10.1167/iovs.02-0601

[8] Wetson, B.C., Bourne, W.M., Polse, K.A. and Hodge, D.O. (1995) Corneal Hydration Control in Diabetes Mellitus. Investigative Ophthalmology and Visual Science, 36, 586-595.

[9] Larsson, L.I., Bourne, W.M., Pach, J.M. and Brubaker, R.F. (1996) Structure and Function of the Corneal Endothelium in Diabetes Mellitus Type I and Type II. Archives of Ophthalmology, 114, 9-14. http://dx.doi.org/10.1001/archopht.1996.01100130007001

[10] Bakunowicz-Łazarczyk, A., Stankiewicz, A., Urban, B. and Średzińska-Kita, D. (1996) Wyniki operacji zaćmy z wszczepieniem sztucznej soczewki u dzieci i młodzieży w latach 1990-1995 (materiał własny). Klinika Oczna, 98, $295-297$.

[11] Brady, K.M., Atkinskon, C.S., Kilty, L.A. and Hiles, D.A. (1995) Cataract Surgery and Intraocular Lens Implantation in Children. American Journal of Ophthalmology, 120, 1-9.

[12] Leurence, C.L., Arne, J.L., Chapotot, E.C., Thouvenin, D. and Malecaze, F. (1998) Visual Outcome after Paediatric Cataract Surgery: Is Age a Major Factor? British Journal of Ophthalmology, 82, 1022-1025. http://dx.doi.org/10.1136/bjo.82.9.1022

[13] Spierer, A., Desatnik, H., Rosner, M. and Blumenthal, M. (1998) Congenital Cataract Surgery in Children with Cataract as an Isolated Defect and in Children with Systemic Syndrome: A Comparative Study. Journal of Pediatric Ophthalmology and Strabismus, 35, 281-285.

[14] Yao, Z., Xie, L., Huang, Y. and Wang, Z. (2002) Preliminary Results of Foldable Intraocular Lens Implantation in Children with Cataract. Chinese Journal of Ophthalmology, 38, 488-490.

[15] Filipek, E., Formińska-Kapuścik, M., Nawrocka, L., Mrukwa-Kominek, E. and Pieczara, E. (2008) Ocena czynności oczu u dzieci i młodzieży po operacji zaćmy rozwojowej i pierwotnym wszczepieniu zwijalnej tylno komorowej soczewki wewnątrzgałkowej. Okulistyka, 4, 29-32.

[16] Filipek, E., Formińska-Kapuścik, M., Nawrocka, L., Pieczara, E. and Domańska, O. (2006) Intraocular Lens Implantation after Congenital Cataract Extraction Infants and Small Children. Polish Journal of Environmental Studies, 15, $73-$ 77.

[17] Filipek, E., Formińska-Kapuścik, M., Nawrocka, L., Samochowiec-Donocik, E. and Pieczara, E. (2006) Visual Acuity and Amblyopia in Pseudophakic Children after Developmental Cataract Surgery. Polish Journal of Environmental Studies, 15, 65-69.

[18] Szalai, E., Nemeth, G., Berta, A. and Modis Jr., L. (2011) Evaluation of the Corneal Endothelium Using Noncontact and Contact Specular Microscopy. Cornea, 30, 567-570.

[19] Bourne, W.M. and Kaufman, H.E. (1976) Specular Microscopy of Human Corneal Endothelium in Vivo. American Journal of Ophthalmology, 81, 319-323. http://dx.doi.org/10.1016/0002-9394(76)90247-6

[20] Liesegang, T.J., Bourne, W.M. and Ilstrup, D.M. (1984) Short- and Long-Term Endothelial Cell Loss Associated with Cataract Extraction and Intraocular Lens Implantation. American Journal of Ophthalmology, 97, 32-39.

[21] Galin, M.A., Lin, L.L., Fetherolf, E., Obstbaum, S.A. and Sugar, A. (1979) Time Analysis of Corneal Endothelial Cell Density after Cataract Extraction. American Journal of Ophthalmology, 88, 93-96.

[22] Olsen, T. (1980) Corneal Thickness and Endothelial Damage after Intracapsular Cataract Extraction. Acta Ophthalmologica, 58, 424-433.

[23] Mrzygłód, S. and Warczyński, A. (1985) Examination of Corneal Endothelium by a Specular Microscope. I. The Types of Microscopes. Klinika Oczna, 87, 23-24.

[24] Urban, B., Bakunowicz-Łazarczyk, A. and Krętowska, M. ( 2005) Ocena śródbłonka rogówki po operacjach usunięcia zaćmy u dzieci i młodzieży. Klinika Oczna, 107, 43-45.

[25] Vasavada, A.R., Praveen, M.R., Vasavada, V.A., Shah, S.K., Vasavada, V. and Trivedi, R.H. (2012) Corneal Endothelial Morphologic Assessment in Pediatric Cataract Surgery with Intraocular Lens Implantation: A Comparison of Preoperative and Early Postoperative Specular Microscopy. American Journal of Ophthalmology, 154, 259-265. 
http://dx.doi.org/10.1016/j.ajo.2012.02.018

[26] Basti, S., Aasuri, M.K., Reddy, S. and Raon, G.N. (1998) Prospective Evaluation of Corneal Endothelial Cell Loss after Pediatric Cataract Surgery. Journal of Cataract \& Refractive Surgery, 24, 1496-1473. http://dx.doi.org/10.1016/S0886-3350(98)80168-5

[27] Hengerer, F.H., Dick, H.B., Buchwald, S., Hutz, W.W. and Conrad-Hengerer, I. (2011) Evaluation of Corneal Cell Loss and Corneal Thickness after Cataract Removal with Light-Adjustable Intraocular Lens Implantation: 12 Month Follow-Up. Journal of Cataract Refractive Surgery, 37, 2095-2100.

[28] Lundberg, B., Jonsson, M. and Behndig, A. (2005) Postoperative Corneal Swelling Correlates Strongly to Corneal Endothelial Cell Loss after Phacoemulsification Cataract Surgery. American Journal of Ophthalmology, 139, 1035-1041. http://dx.doi.org/10.1016/j.ajo.2004.12.080

[29] Faramazi, A., Javadi, M.A., Bonyadi, M.H.J. and Yaseri, M. (2010) Changes in Central Corneal Thickness after Congenital Cataract Surgery. Journal of Cataract \& Refractive Surgery, 36, 2041-2047. http://dx.doi.org/10.1016/j.jcrs.2010.07.016 